\title{
STUDI IMPLEMENTASI KEBIJAKAN KOTA LAYAK ANAK (KLA) DI KOTA PEKANBARU
}

\author{
Mustiqowati Ummul Fithriyyah \\ Universitas Islam Negeri Sultan Syarif Kasim \\ mustiqoumulfitria@gmail.com
}

\begin{abstract}
Abstrak. KLA dimaksudkan sebagai usaha nyata untuk pembangunan kabupaten dan kota. Perkembangan perawatan anak pada dasarnya adalah suatu kondisi untuk penghormatan, perlindungan dan pemenuhan hak anak.

KLA di Pekanbaru telah diluncurkan melalui pembentukan Task Force, namun tetap saja ada perubahan yang berarti. Secara umum bisa dikatakan bahwa isu pergerakan pemerintah kota Pekanbaru dan gerakan perlindungan anak belum dilakukan secara optimal. Perubahan tersebut diperkirakan tidak akan signifikan. Penelitian ini untuk mengetahui "kenapa bukan kebijakan yang optimal?"

Kendala di KLA di Pekanbaru adalah sebagai berikut: (1) Program KLA belum populer di tingkat SKPD di Pekanbaru dan secara kelembagaan SKPD masih bersifat egosektoral sehingga sulit untuk mengintegrasikan isu Anak dalam penyusunan program pendidikan, dan persiapan RAD-KLA, (2) penerapan kapasitas kelembagaan yang tidak memadai. (3) Tidak adanya anggaran berdasarkan kebutuhan anak dalam anggaran, (4) Tidak untuk menjalin kemitraan antara pemerintah, sektor swasta, organisasi masyarakat, dan masyarakat sendiri, termasuk anak-anak, dalam mewujudkan Pekanbaru ke Kota Anak-anak yang memenuhi syarat sesuai dengan yang tercantum dalam Peraturan Menteri Negara PPPA RI. 12 tahun 2011
\end{abstract}

Kata kunci: Kebijakan imlementasi anak kota yang sesuai

Abstract. The policy imlementation of children appropriate city known as (KLA) is intended as a real effort to unite children rights issues into the planning and construction of district / city. Children care development is basically a condition for the respect, protection and fulfillment of children's rights.

The policy imlementation of children appropriate city known as (KLA) in Pekanbaru has been launched through the establishment of the Task Force, but yet there appears to be a significant change. In general it can be said that the issue of Children has not been a priority in policy and budgeting in Pekanbaru city government and child protection movement has not been done optimally. The changes are not expected to be significant. This research is to know "why The policy imlementation of children appropriate city known as (KLA) in Pekanbaru is not optimal?"

Obstacles in The policy imlementation of children appropriate city known as (KLA) in Pekanbaru are as follows: (1) Program KLA has not been popular in the levels SKPD in Pekanbaru and institutionally SKPD still egosektoral making it difficult to integrate the issue of Children in the preparation of programs on education, and also the preparation of $R A D-K L A$, (2) implementing inadequate institutional capacity. (3) The absence of a budget based on the needs of children in the budget, (4) Not to achieve a partnership between government, private sector, community organizations, and the community itself, including children, in realizing Pekanbaru into the City of Eligible Children in accordance with the indicators specified in Peraturan Menteri Negara PPPA RI No. 12 in 2011.

Keyword: The policy imlementation of children appropriate city 


\section{PENDAHULUAN}

\section{Latar Belakang}

"Harta dan anak-anak adalah perhiasan kehidupan dunia, namun amal yang kekal dan shalih adalah lebih pahalanya di sisi Tuhanmu serta lebih baik untuk menjadi harapan”. (Q.S.Al Kahfi: 46).

Ayat di atas menyatakan bahwa anak adalah sebagai hiasan yang memperindah sebuah keluarga. Tangisannya, rengekannya, celotehannya yang lucu, merupakan bagianbagian indah dalam sebuah keluarga. Dalam Q.S. Al Furqon: 74 juga dinyatakan bahwa anak adalah sebagai penyejuk mata, penyejuk hati (qurrota a'yun). Dikatakan demikian karena ketika mata kita memandang anak maka akan timbul rasa bahagia.

Anak adalah anugerah dan kado terindah dari Tuhan bagi setiap keluarga. Anak adalah sebagai amanah yang dipercayakan Allah swt kepada manusia yang harus dijaga dan dipelihara dengan sebaikbaiknya agar mereka bisa tumbuh dan berkembang dengan baik dalam lingkungan yang aman dan stabil serta suasana yang bahagia, penuh kasih dan pengertian. Selain itu, anak sebagai generasi penerus bangsa merupakan investasi masa depan bagi bangsa dan negara. Oleh karena itu anak harus dijaga dan dilindungi segala harkat dan martabatnya, kepentingan-kepentingannya serta hakhaknya. Hak secara fisik, psikis, maupun intelektual -hak hidup, hak tumbuh, hak dicintai, hak berbicara, hak berekspresi, dan menentukan diri mereka sendiri.

Perlindungan anak mutlak diwujudkan oleh setiap elemen masyarakat dan tentunya dijamin keberadaannya oleh negara agar anak dapat tumbuh dan berkembang secara wajar. Sesuai dengan Undang-Undang No.23 Tahun 2002 tentang Perlindungan Anak, perlindungan anak mencakup anak yang belum berusia 18 tahun, termasuk anak yang masih dalam kandungan, dan meliputi hakhak anak untuk hidup, tumbuh, berkembang, dan berpartisipasi dalam berbagai aspek kehidupan serta mendapat perlindungan dari berbagai bentuk kekerasan dan diskriminasi.
Dengan demikian, perlindungan anak mencakup setiap bidang pembangunan. Pembangunan perlindungan anak yang terintegrasi dan komprehensif akan menghasilkan kebijakan publik yang lebih efektif dalam mewujudkan dunia yang layak bagi seluruh anak Indonesia, baik laki-laki maupun perempuan (LAKIP KPP-P, 2013: 6).

Meskipun regulasi tentang perlindungan terhadap anak telah disusun demikian rapinya, namun masih terdapat pemahaman yang berbeda-beda di kalangan para orangtua dan masyarakat mengenai arti anak. Pada sebagian orangtua memahami anak sebagai 'amanah' dan 'titipan' yang harus dilindungi dan dihargai. Sedangkan pada sebagian orangtua 'anak' sebagai 'aset keluarga' dan 'anak harus mengerti orangtua. Pemahaman yang terakhir ini kadang-kadang anak menjadi korban perdagangan anak, eksploitasi ekonomi dan seksual, serta tumbuh dan berkembangnya terabaikan. Begitu banyak pemberitaan tentang kekerasaan terhadap anak; anak lahir dan mati di kamar mandi, anak disiksa, dicabuli, dieksploitasi, dipekerjakan di bawah umur, dan dinikahkan pada usia dini dengan alasan ekonomi. Sederet contoh ini merupakan bukti bahwa keluarga sebagai institusi terkecil dalam masyarkat belum seluruhnya ramah terhadap anak.

Selain keluarga, perlakuan lingkungan bermain, lingkungan tempat belajar, dan fasilitas publik yang disediakan pemerintah, seperti jalan, alat transportasi, tempat rekreasi, dan lainnya ternyata juga belum ramah terhadap anak (Naning, 2009: 4). Padahal negara telah dengan jelas mengatur tentang hak-hak anak, sebagaimana yang tertuang dalam Undang-undang Dasar Tahun 1946 pasal 28B ayat 2, "setiap anak berhak atas kelangsungan hidup, tumbuh, dan berkembang serta berhak atas perlindungan dari kekerasan dan diskriminasi”. Fakta tersebut menunjukkan bahwa meskipun telah ada regulasi yang melindungi anak, namun persoalan kekerasan terhadap anak masih seringkali terjadi.

Selain UUD 1945, beberapa regulasi yang menjelaskan tentang perlindungan anak adalah Undang-undang Nomor 23 Tahun 
2002 tentang Perlindungan Anak sebagai Pelaksanaan Konvensi PBB tentang Hak Anak, Undang-undang Nomor 23 Tahun 2004 tentang Pencegahan Kekerasan dalam Rumah Tangga (PKDRT), Undang-undang Nomor 23 Tahun Nomor 17 Tahun 2007 tentang Rencana Pembangunan Jangka Panjang Nasional (RPJPN) 2005-2025 yang memuat upaya pemerintah dalam meningkatkan kesejahteraan anak dan mewujudkan anak Indonesia yang sehat, cerdas, ceria, dan berakhlak mulia serta melindungi anak terhadap berbagai bentuk kekerasan, eksploitasi, dan diskriminasi.

Kemudian Kementerian Negara Pemberdayaan Perempuan (KPP) bersama sektor pemerintah terkait, organisasi masyarakat, dan lembaga swadaya masyarakat mengembangkan model Kota Layak Anak, yaitu kota yang di dalamnya telah mempunyai sistem pembangunan berbasis hak anak melalui pengintegrasian komitmen dan sumber daya pemerintah, masyarakat dan dunia usaha yang terencana secara menyeluruh dan berkelanjutan dalam kebijakan, program dan kegiatan untuk menjamin terpenuhinya hak anak. KLA dimaksudkan sebagai sebuah upaya nyata untuk menyatukan isu hak anak ke dalam perencanaan dan pembangunan kabupaten/kota. Pembangunan yang peduli anak pada dasarnya adalah suatu kondisi adanya penghormatan, perlindungan, dan pemenuhan hak anak.

Dalam rangka mempercepat terwujudnya pengembangan Kota Layak Anak, Kementerian Pemberdayaan Perempuan dan Perlindungan Anak telah menjadikan model KLA ini sebagai prioritas program dalam bidang kesejahteraan dan perlindungan anak dengan menetapkan 7 (tujuh) aspek penting dalam pengembangan KLA, yaitu: 1) kesehatan; 2) pendidikan; 3) sosial; 4) hak sipil dan partisipasi; 5) perlindungan hukum; 6) perlindungan ketenagakerjaan; 7) infrastruktur.

Menindaklanjuti kebijakan nasional tersebut, masing-masing pemerintah daerah menetapkan kebijakan yang dimaksudkan untuk melindungi hak-hak anak yang disesuaikan dengan kebutuhan daerah dan kondisi ekonomi daerahnya. Namun tampaknya kebijakan Kota Layak Anak masih belum terlalu menjadi prioritas pada pemerintah provinsi Riau dan khususnya di pemerintah Kota Pekanbaru. Hal ini ditandai dengan sebuah fakta bahwa baru pada tahun 2013 dikeluarkan Perda Provinsi Riau tentang Perlindungan dan Hak Dasar Anak (Perda Provinsi Riau No.3 Tahun 2013). Keluarnya Perda provinsi Riau tersebut, dinilai sangat terlambat jika dibandingkan dengan keluarnya kebijakan nasional tentang Kota Layak Anak yang telah dirintis sejak 2006.

Sedangkan untuk Pemerintah Kota Pekanbaru, baru sampai pada keluarnya Surat Keputusan Walikota No. 602/XII/2006 tentang pembentukan Komisi Perlindungan Anak Indonesia Daerah (KPAID), yang secara umum memiliki tugas dan fungsi untuk melindungi hak-hak anak di Kota Pekanbaru. Namun karena permasalahan internal, maka pada tahun 2011 KPAID Pekanbaru dibubarkan dan kemudian digantikan dengan pembentukan Pusat Pelayanan Terpadu Pemberdayaan Perempuan dan Anak (P2TP2A) kota Pekanbaru tahun 2012-2025, melalui Keputusan Walikota Pekanbaru No. 231 Tahun 2013. Kemudian regulasi lainnya adalah terbitnya Surat Keputusan Walikota Pekanbaru No. 144 Tahun 2013 tentang Pembentukan Gugus Tugas Pengembangan KLA Kota Pekanbaru -Gugus Tugas KLA Kabupaten/Kota adalah lembaga koordinatif di tingkat kabupaten/kota yang mengkoordinasikan upaya kebijakan, program, dan kegiatan untuk mewujudkan KLA. Selain itu, terkait dengan pengembangan KLA ini, Pemerintah Kota Pekanbaru mengeluarkan Keputusan Walikota Pekanbaru Nomor 386 Tahun 2013 tentang Pembentukan Pengurus Forum Anak Kota Pekanbaru Tahun 2013-2016.

Namun, secara umum dapat dikatakan bahwa issue anak belum menjadi prioritas dalam kebijakan dan penganggaran di pemerintah Kota Pekanbaru dan gerakan perlindungan anak belum dilakukan secara maksimal. Perubahan-perubahan yang diharapkan belum signifikan. Contohnya: masih banyak ditemukan permasalahanpermasalahan pada anak, di antaranya kekerasan psikis, kekerasan fisik dan penelantaran ekonomi, kekerasan ekonomi, 
eksploitasi, trafficking, pelecehan seksual, masih banykanya terlihat anak yang mengamen ataupun mengemis di tepian jalan atau pada traffict light (lampu merah), masih banyaknya anak-anak yang terpaksa bekerja (dipekerjakan) pada saat jam belajar anak, karena orangtua yang tidak dapat memenuhi kebutuhannya, belum adanya shelter untuk anak sebagai pelaku, dan meningkatnya jumlah anak penderita ISPA. Berikut data korban tindakan kekerasan terhadap anak di kota Pekanbaru dalam kurun waktu 5 tahun, sejak tahun 2010 sampai tahun 2010.

Tabel 1.1

Data Penyandang Masalah Kesejahteraan Sosial (PMKS) dan Korban Tindakan Kekerasan (KTK) Kota Pekanbaru Tahun 2010-2014

\begin{tabular}{|c|c|c|c|c|c|c|}
\hline No & $\begin{array}{c}\text { Jenis } \\
\text { Kekerasan }\end{array}$ & Th 2010 & Th 2011 & Th 2012 & Th 2013 & Th 2014 \\
\hline 1. & KF & 16 & 23 & 27 & 31 & 38 \\
\hline 2. & KP & 11 & 14 & 20 & 23 & 30 \\
\hline 3. & KE & 12 & 14 & 16 & 20 & 25 \\
\hline 4. & KS & 11 & 15 & 19 & 24 & 30 \\
\hline 5. & EKS & 5 & 5 & 8 & 12 & 17 \\
\hline 6. & TRF & 7 & 8 & 14 & 16 & 18 \\
\hline \multicolumn{2}{|c|}{ JUMLAH } & $\mathbf{6 2}$ & $\mathbf{7 9}$ & $\mathbf{1 0 4}$ & $\mathbf{1 2 6}$ & $\mathbf{1 5 8}$ \\
\hline
\end{tabular}

Sumber: Dinas Sosial dan Pemakaman Umum Kota Pekanbaru, 2015

Keterangan:

$\begin{array}{ll}\text { KF } & \text { : Kekerasan Fisik } \\ \text { KP } & \text { : Kekerasan psikis } \\ \text { KE } & \text { : Kekerasan Ekonomi } \\ \text { KS } & \text { : Kekerasan Ekonomi } \\ \text { EKS } & \text { : Eksploitasi } \\ \text { TRF } & \text { : Trafficking }\end{array}$

Tabel di atas menunjukkan tingginya perlakuan tindak kekerasan terhadap anak di Pekanbaru. Selain itu, ada juga kekerasan ekonomi yang sering dialami oleh anak. Mereka terpaksa bekerja dikarenakan keterbatasan ekonomi sehingga anak membantu orangtuanya bekerja, bahkan ada beberapa anak yang hidup di jalanan menjadi pengemis dan gelandangan.

Kemudian permasalahan yang barubaru ini (sebetulnya menjadi bencana musiman) sangat meresahkan warga Pekanbaru, yaitu dampak dari kebakaran hutan dan lahan yang kemudian menimbulkan banyaknya warga yang terkena penyakit ISPA. Berikut data penderita ISPA di Provinsi Riau dan termasuk Kota Pekanbaru.

Tabel 1.2.

Jumlah Anak Jalanan Menurut Jenis Kelamin di Kota Pekanbaru Tahun 2014-2016

\begin{tabular}{|c|c|c|c|c|}
\hline No & Tahun & Laki-laki & Perempuan & Jumlah \\
\hline 1. & 2014 & 37 orang & 16 orang & 53 orang \\
\hline 2. & 2015 & 12 orang & 42 orang & 54 orang \\
\hline 3. & 2016 & 14 orang & 3 orang & 17 orang \\
\hline \multicolumn{2}{|c|}{ Jumlah } & 63 orang & 61 orang & 124 orang \\
\hline
\end{tabular}

Sumber: Dinas Sosial Kota Pekanbaru, 2016 
Mustiqowati Ummul Fithriyyah, Studi Implementasi Kebijakan Kota Layak Anak KLA...

Berikut ini akan disajikan mengenai data banyak nya anak terlantar menurut jenis kelamin dan kecamatan di kota Pekanbaru;

Tabel 1.3.

Data Banyaknya Anak Terlantar Menurut Jenis Kelamin dan Kecamatan Di Kota Pekanbaru

Tahun 2013

\begin{tabular}{|c|c|c|c|c|}
\hline \multirow{2}{*}{ No } & \multirow{2}{*}{ Kecamatan } & \multicolumn{2}{|c|}{ Jenis Kelamin } & \multirow{2}{*}{ Jumlah } \\
\cline { 3 - 4 } & & Lak-laki & Perempuan & \\
\hline 1 & Tampan & 155 & 95 & 250 \\
\hline 2 & Payung Sekaki & 80 & 50 & 130 \\
\hline 3 & Bukit Raya & 76 & 29 & 105 \\
\hline 4 & Marpoyan Damai & 28 & 22 & 50 \\
\hline 5 & Tenayan Raya & 120 & 119 & 239 \\
\hline 6 & Lima Puluh & 22 & 14 & 36 \\
\hline 7 & Sail & 61 & 14 & 75 \\
\hline 8 & Pekanbaru Kota & 52 & 39 & 91 \\
\hline 9 & Sukajadi & 9 & 4 & 13 \\
\hline 10 & Senapelan & 69 & 29 & 98 \\
\hline 11 & Rumbai & 102 & 61 & 163 \\
\hline 12 & Rumbai Pesisir & 134 & 76 & 210 \\
\hline & JUMLAH & $\mathbf{9 0 8}$ & $\mathbf{5 5 2}$ & $\mathbf{1 . 4 6 0}$ \\
\hline
\end{tabular}

Sumber: Dinas Sosial dan Pemakaman Kota Pekanbaru, 2014

Tabel di atas menunjukkan tingginya angka anak terlantar di Pekanbaru. Hal ini bisa disebabkan keterbatasan ekonomi, bahkan ada beberapa anak yang hidup di jalanan menjadi pengemis dan gelandangan.
Pemandangan seperti itu sering kita jumpai di pinggiran jalan atau di traffict light (lampu merah). Kondisi ini diperparah dengan banyaknya jumlah anak nakal yang terlihat dari tabel berikut ini;

Tabel 1.4.

Data Banyaknya Anak Nakal dan Wanita Rawan Sosial Ekonomi Di Kota Pekanbaru

Tahun 2013

\begin{tabular}{|c|c|c|c|}
\hline No & Kecamatan & Anak Nakal & $\begin{array}{l}\text { Wanita Rawan } \\
\text { Sosial Ekonomi }\end{array}$ \\
\hline 1 & Tampan & 21 & 210 \\
\hline 2 & Payung Sekaki & 16 & 168 \\
\hline 3 & Bukit Raya & 17 & 255 \\
\hline 4 & Marpoyan Damai & 17 & 142 \\
\hline 5 & Tenayan Raya & 14 & 169 \\
\hline 6 & Lima Puluh & 17 & 167 \\
\hline 7 & Sail & 16 & 66 \\
\hline 8 & Pekanbaru Kota & 16 & 165 \\
\hline 9 & Sukajadi & 21 & 265 \\
\hline 10 & Senapelan & 21 & 85 \\
\hline 11 & Rumbai & 17 & 183 \\
\hline 12 & Rumbai Pesisir & 17 & 125 \\
\hline & JUMLAH & $\mathbf{2 1 0}$ & $\mathbf{2 . 0 0 0}$ \\
\hline
\end{tabular}


Sumber: Dinas Sosial dan Pemakaman Kota Pekanbaru, 2014

Kondisi kekerasan terhadap anak di Kota Pekanbaru terus meningkat dan semakin memprihatinkan, hingga Pekanbaru sempat mendapatkan julukan Kota Darurat Anak, sebagaimana yang disampaikan Helda Khamsy Kepala P2TP2A Kota Pekanbaru dalam Pekanbaru Pos edisi 20 Februari 2015.

"Tren peningkatan kasus selalu terjadi tiap tahun, Pekanbaru bisa dikatakan kota darurat anak"

Membincang tentang problematika anak, meskipun telah banyak regulasi yang mengatur tentang perlindungan anak namun tetap saja tindak kekerasan terhadap anak terus saja terjadi. Dan apapun bentuknya, baik kekerasan fisik, psikis, ekonomi, maupun seksual, pastilah mendatangkan ketidakadilan dan memunculkan kepedihan dan penderitaan bagi korbannya. Kasus kekerasan yang tak kalah berbahayanya adalah pemaksaan kehendak kepada anak seprti jadwal belajar dan kursus yang overload. Selain itu, ada juga bentuk pembiaran terhadap anak, seperti anak Selain keluarga yang tidak ramah terhadap anak, fasilitas publik yang tersedia di Kota Pekanbaru juga belum sensitif terhadap anak, terbukti dengan minimnya tempat bermain anak. Kemudian persoalan anak yang lain yang tak kalah penting adalah sangat minimnya ruang berpartisipasi di ruang publik, baik dalam hal perencanaan, pelaksanaan, maupun evaluasi.

Selain data di atas, partisipasi anak dalam keluarga, sekolah, dan masyarakat masih minim dan begitu juga partisipasi anak dalam pembangunan di Kota Pekanbaru khususnya dalam proses-proses kebijakan seperti Musyawarah Rencana Pembangunan Kecamatan (Musrenbangcam), dan Musyawarah Rencana Pembangunan (Musrenbang) pun belum nampak, yang mana hal-hal ini merupakan aspek penting dalam terwujudnya kota layak anak.

\section{Rumusan Masalah}

Kebijakan Kota Layak Anak di Kota Pekanbaru telah dicanangkan melalui pembentukan Gugus Tugas, namun belum tampak ada perubahan yang signifikan mengenai perlindungan terhadap hak-hak anak di Kota Pekanbaru, maka rumusan masalah dalam penelitian ini adalah sebagai berikut: (1) Bagaimana implementasi kebijakan Kota Layak Anak (KLA) di Kota Pekanbaru (2) mengapa implementasi kebijakan Kota Layak Anak (KLA) di Kota Pekanbaru belum optimal, apa faktor yang mempengaruhi implementasi kebijakan Kota Layak Anak (KLA) di Kota Pekanbaru?

\section{Tujuan dan Manfaat Penelitian}

Penelitian ini bertujuan untuk (1) Memperoleh gambaran mengenai impementasi kebijakan pengembangan Kota Layak Anak di Kota Pekanbaru, dan (2) Menemukan faktor-faktor yang mempengaruhi implementasi kebijakan pengembangan Kota Layak Anak di Kota Pekanbaru.

Sedangkan manfaat penelitian ini adalah; (1) secara akademis penelitian ini memberi sumbangan teoritis terhadap khazanah keilmuan administrasi negara da kajian gender dan anak, tentang pentingya mengintegrasikan kebutuhan, kepentingan, dan spirasi anak, (2) manfaat praktis penelitian ini adalah agar menjadi bahan refleksi dan evaluasi bagi Pemerintah Kota Pekanbaru dalam melaksanakan serta mengembangkan kebijakan Kota Layak Anak, (3) manfaat praktis lainnya adalah sebagai daya dorong bagi pihak lain untuk melakukan penelitian atau kajian-kajian terhadap anak khususnya yang terkait dengan aspek-aspek penting yang telah dijelaskan dalam kebijakan Kota Layak Anak.

\section{KAJIAN PUSTAKA}

\section{Pengertian Anak}

Anak secara umum dipahai masyarakat sebagai keturunan kedua setelah ayah dan ibu (WJS. Poedarminta, Kamus Umum Bahasa 
Indonesia, Jakarta: Balai Pustaka. 1992 : 3839).

Anak merupakan amanah Tuhan Yang Maha Esa yang harus dilindungi hak asasinya sebagai manusia, karena merupakan individu yang belum matang secara fisik, mental maupun sosial. Kondisinya rentan dan masih tergantung pada orang dewasa. Oleh karena itu anak memerlukan perlindungan baik oleh keluarga, masyarakat, maupun negara (Siti, 2011: 400).

Selain itu Undang - Undang Kesejahteraan anak, mendefinisikan bahwa anak adalah seseorang yang belum mencapai umur 21 tahun dan belum pernah menikah (Pasal 1 (2), UU No.4 tahun 1974 tentang Kesejahteraan Anak). Sedangkan dalam Undang - Undang Perkawinan, anak adalah seseorang yang belum mencapai usia 18 tahun (Pasal 47 UU No.1 tahun 1974, tentang Perkawinan).

Berdasarkan UU Peradilan Anak. Anak dalam UU No.3 tahun 1997 tercantum dalam pasal 1 ayat (2) yang berbunyi: “ Anak adalah orang dalam perkara anak nakal yang telah mencapai umur 8 (delapan) tahun tetapi belum mencapai umur 18 tahun (delapan belas) tahun dan belum pernah menikah. Sedangkan Undang-undang Ketenagakerjaan memberi batasan bahwa usia anak adalah sampai 15 tahun dan Undang-undang pemilu mendefinisikan anak adalah mereka yang berusia kurang dari 17 tahun.

Sementara itu dalam Panduan KLA dijelaskan anak adalah seseorang yang belum berusia 18 (delapan belas) tahun, termasuk anak yang masih dalam kandungan (Panduan Pengembangan KLA, 2011). Hal ini senada dengan yang dinyatakan dalam Konvensi Hak Anak, bahwa anak adalah setiap manusia yang berusia di bawah 18 tahun, kecuali berdasarkan undang-undang yang berlaku untuk anak-anak, kedewasaan telah dicapai lebih cepat (KHA Pasal 1, disetujui oleh Majelis Umum PBB pada 20 November 1989). Dan Pasal 1 (1) UU No. 23/2002 tentang Perlindungan Anak menyebutkan bahwa hak anak bagian dari ham yang wajib dijamin, dilindungi dan dipenuhi oleh orang tua, keluarga, masyarakat, pemerintah dan negara.
Anak merupakan potensi bangsa bagi pembangunan nasional, untuk itu pembinaan dan pengembangannya perlu dilakukan sedini mungkin dengan mendorong pemerintah Kabupaten.Kota untuk menyusun kebijakan yang berpihak pada kepentingan anak. Indonesia sebagai salah satu negara yang meratifikasi Konvensi Hak Anak melalui Keputusan Presiden Nomor 36 Tahun 1990, berkewajiban untuk membuat langkahlangkah yang diperlukan bagi peningkatan kesejahteraan anak dan pemenuhan hak-hak anak.

Indonesia yang juga telah ikut menandatangani Deklarasi Dunia yang Layak bagi Anak (World Fit For Children) perlu mengembangkan rencana aksi untuk menjadikan Kabupaten/Kota Layak Anak sebagai bentuk pelaksanaan WFFC; dalam rangka melaksanakan Peraturan Pemerintah Nomor 38 Tahun 2007 tentang Pembagian Urusan Pemerintahan antara Pemerintah, Pemerintah Daerah Provinsi, dan Pmerintah Daerah Kabupaten/Kota, khususnya terkait dengan norma standar, prosedur dan kriteria urusan wajib Pemberdayaan Perempuan dan Perlindungan Anak, maka salah satu program yang ditetapkan adalah Kebijakan Kabupaten/Kota Layak Anak.

\section{Kota Layak Anak}

Dalam buku pedoman Kota Layak Anak (2006) dijelaskan bahwa Kota Layak Anak (KLA) merupakan istilah yang diperkenalkan pertama kali oleh Kementerian Negara Pemberdayaan Perempuan pada tahun 2006 melalui kebijakan Kota Layak Anak, karena alasan untuk mengakomodasi persoalan anak di setiap pemerintahan kota / kabupaten di Indonesia. Dalam kebijakan KLA tersebut digambarkan bahwa KLA merupakan upaya pemerintah untuk mempercepat implementasi Konvensi Hak Anak dari kerangka hukum ke dalam definisi, strategi, dan intervensi pembangunan seperti kebijakan, institusi, dan program yang layak anak.

Pedoman Kota Layak Anak tahun 2006 kemudian terus disempurnakan, dan sesuai dengan Panduan Pengembangan KLA tahun 2011 dijelaskan bahwa Kota Layak Anak yaitu kota yang di dalamnya telah mempunyai 
sistem pembangunan berbasis hak anak melalui pengintegrasian komitmen dan sumber daya pemerintah, masyarakat dan dunia usaha yang terencana secara menyeluruh dan berkelanjutan dalam kebijakan, program dan kegiatan untuk menjamin terpenuhinya hak anak.

Gagasan Kota Layak Anak sebelumnya telah diawali oleh Kevin Lynch (arsitek dari Massachussets Institute of Technology) dalam peenelitiannya yang berjudul "Children's Perception of the Environment". Hasil penelitiannya tersebut mengatakan bahwa lingkungan yang terbaik untuk anak adalah yang mempunyai komuniti yang kuat secara fisik dan sosial, komuniti yang mempunyai aturan yang jelas dan tegas, komuniti yang memberi kesempatan pada anak, dan komuniti yang mempunyai fasilitas pendidikan yang memberi kesempatan anak untuk mempelajari dan menyelidiki lingkungan dan dunia mereka (Pattilima, 2004: 1). Dan dari penelitian lainnya mengenai anak, yang menarik adalah anak dapat diajakn kerjasama dan mengatasi persoalan-persoalan yang berhubungan dengan kota (Adams \& Ingham, 1998 dalam Hamid Pattilina, 2008). Hal ini tentu tidak begitu saja mudah untuk dilakukan, sebagaimana dikatakan oleh Alit Kurniasari bahwa untuk mewujudkan komuniti peduli anak dibutuhkan adanya pembentukan jejaring kolaboratif antar sektor terkait, dunia usaha, masyarakat peduli anak, dan pemerintah. (www.depsos.go.id, 14 Juni 2010).

KLA dimaksudkan sebagai sebuah upaya nyata untuk menyatukan isu hak anak ke dalam perencanaan dan pembangunan kabupaten/kota. Pembangunan yang peduli anak pada dasarnya adalah suatu kondisi adanya penghormatan, perlindungan, dan pemenuhan hak anak.

Dalam rangka mempercepat terwujudnya pengembangan Kota Layak Anak, Kementerian Pemberdayaan Perempuan dan Perlindungan Anak telah menjadikan model KLA ini sebagai prioritas program dalam bidang kesejahteraan dan perlindungan anak dengan menetapkan 7 (tujuh) aspek penting dalam pengembangan KLA, yaitu: 1) kesehatan; 2) pendidikan; 3) sosial; 4) hak sipil dan partisipasi; 5) perlindungan hukum; 6) perlindungan ketenagakerjaan; 7) infrastruktur (Pedoman Kebijakan KLA, 2006).

Kronologis munculnya Kebijakan KLA; sejak tahun 2006 telah disusun rancangan kebijakan kota/kabupaten layak anak (KLA) yang di inisiasi oleh Kementerian Pemberdayaan Perempuan (KPP). Sebagai langkah awal pengembangan KLA, tahun 2006 Kementerian Negara Pemberdayaan Perempuan telah melakukan ujicoba pengembangan KLA di 5 kabupaten/kota, yaitu Kota Jambi di Provinsi Jambi, Kota Surakarta (Solo) di Provinsi Jawa Tengah, Kabupaten Sidoarjo di Provinsi Jawa Timur, Kabupaten Kutai Kartanegara di Provinsi Kalimantan Timur, dan terakhir Kabupaten Gorontalo di Provinsi Gorontalo. Sedangkan pada tahun 2007 ditunjuk 10 kabupaten/kota, yaitu Aceh Besar (Nanggroe Aceh Darussalam), Kabupaten OKI (Sumatera Selatan), Kota Padang (Sumatera Barat), Lampung Selatan (Lampung), Kabupaten Karawang (Jawa Barat), Kabupaten Sragen (Jawa Tengah), Kota Malang (Jawa Timur), Kota Pontianak (Kalimantan Barat), Kota Manado (Sulawesi Utara), dan Kota Kupang (Nusa Tenggara Timur). Dan pengembangan KLA terus berkembang sampai sekarang.

Untuk mempercepat pemenuhan hakhak anak, telah disusun kebijakan Kabupaten/Kota Layak Anak (KLA) dan telah ditetapkan melalui Peraturan Menteri Negara Pemberdayaan Perempuan Nomor 2 tahun 2009 tentang kebijakan Kota/Kabupaten Layak Anak, dengan didukung oleh Pedoman Pengembangan KLA Tingkat Provinsi (Peraturan Meneg P\&PA No.12 Tahun 2010) dan Petunjuk Teknis KLA di Desa/Kelurahan (Peraturan Meneg PP\&PA No. 14 Tahun 2010).

Dan regulasi tentang pengembangan KLA ini terus disempurnakan yang kemudian secara lebih jelas dituangkan dalam Peraturan Menteri Negara Pemberdayaan Perempuan dan Perlindungan Anak Republik Indonesia Nomor 11 tahun 2011 tentang Kebijakan 
Pengembangan Kabupaten/Kota Layak Anak, Nomor 12 tahun 2011 tentang Indikator Kabupaten/Kota Layak Anak, Nomor 13 tahun 2011 tentang Panduan Pengembangan Kabupaten/Kota Layak Anak (KLA), dan Nomor 14 tahun 2011 tentang Panduan Evaluasi Kabupaten/Kota Layak Anak.

Dalam Peraturan Menteri Negara Pemberdayaan Perempuan dan Perlindungan Anak RI No. 12 Tahun 2011 pasal 5 disebutkan setiap kabupaten/kota dapat dikategorikan sebagai KLA apabila telah memenuhi hak anak yang diukur dengan indikator KLA. Indikator KLA tersebut harus memenuhi 5 (lima) klaster hak anak, yaitu; (1) hak sipil dan kebebasan, (2) lingkungan keluarga dan pengasuhan alternatif, (3) kesehatan dasar dan kesejahteraan, (4) pendidikan, pemanfaatan waktu luang, dan kegiatan budaya, dan (5) perlindungan khusus. Selanjutnya dengan adanya kebijakan KLA ini diharapkan anak sebagai warga kota dapat mempunyai keputusan yang dapat mempengaruhi kotanya; dapat mengekspresikan pendapatnya mengenai kota yang mereka inginkan; dapat berperan serta dalam kehidupan keluarga, komuniti dan sosial; dapat mengakses pelayanan dasar seperti kesehatan dan pendidikan; dapat mengakses air minum segar dan tinggal di lingkungan dengan sanitasi yang baik; terlindungi dari eksploitasi, kekerasan dan penelantaran; merasa aman berjalan di jalan; dapat bertemu dan bermain dengan temannya; hidup di lingkungan yang bebas polusi; berperan serta dalam kegiatan budaya dan sosial; dan secara seimbang dapat mengakses setiap pelayanan tanpa memperhatikan suku bangsa, agama, kekayaan, gender, dan kondisi fisik.

Di Kota Pekanbaru sendiri kebijakan kota layak anak tersebut baru sampai pada keluarnya kebijakan tentang pembentukan Komisi Perlindungan Anak Indonesia Daerah (KPAID), yang didasarkan pada Keputusan Gubernur Riau No. 602/XII/2006 tanggal 15 Desember 2006. Secara umum Komisi Perlindungan Anak Indonesia Daerah (KPAID) ini memiliki tugas dan fungsi untuk melindungi hak-hak anak di Kota Pekanbaru. Kemudian pada tahun 2011 KPAID Pekanbaru digantikan dengan pembentukan
Pusat Pelayanan Terpadu Pemberdayaan Perempuan dan Anak (P2TP2A) kota Pekanbaru tahun 2012-2025, melalui Keputusan Walikota Pekanbaru No. 231 Tahun 2013. Kemudian regulasi lainnya adalah terbitnya Surat Keputusan Walikota Pekanbaru No. 144 Tahun 2013 tentang Pembentukan Gugus Tugas Pengembangan KLA Kota Pekanbaru -Gugus Tugas KLA Kabupaten/Kota adalah lembaga koordinatif di tingkat kabupaten/kota yang mengkoordinasikan upaya kebijakan, program, dan kegiatan untuk mewujudkan KLA. Selain itu, terkait dengan pengembangan KLA ini, Pemerintah Kota Pekanbaru mengeluarkan Keputusan Walikota Pekanbaru Nomor 386 Tahun 2013 tentang Pembentukan Pengurus Forum Anak Kota Pekanbaru Tahun 2013-2016.

Namun, setelah sekian tahun sejak dikeluarkannya pertama kali gagasan KLA hingga menjadi sebuah kebijakan dan juga telah ditindaklanjuti di tingkat daerah, secara umum dapat dikatakan bahwa issue anak belum menjadi prioritas dalam kebijakan dan penganggaran di pemerintah Kota Pekanbaru dan gerakan perlindungan pun anak belum dilakukan secara optimal. Perubahanperubahan yang diharapkan belum signifikan, yang ini artinya, tujuan-tujuan dari dibuatnya kebijakan banyak yang belum tercapai, padahal sebagaimana yang ditulis oleh Riant Nugroho (2009: 494), implementasi sebuah kebijakan pada prinsipnya adalah cara agar kebijakan dapat mencapai tujuannya. Contoh nyata belum terlaksananya kebijakan Kota Layak Anak ini adalah belum tersedianya data base anak di Kota Pekanbaru; belum memadainya penyediaan shalter, belum amannya anak dari gangguan polusi, partisipasi anak dalam pembangunan sama sekali tidak ada.

\section{Implementasi Kebijakan}

Mengenai implementasi kebijakan ini, George C. Edward III juga mengatakan bahwa berhasil tidaknya sebuah implementasi dipengaruhi oleh empat hal, yaitu: komunikasi, sumberdaya, disposisi/karakteristik yang dimiliki implementor, dan struktur birokrasi. Senada 
dengan teori Edward III tersebut, Donald S Van Matter dan Carl EE. Van Horn juga mengungkapkan bahwa keberhasilan sebuah implementasi dipengaruhi oleh sumberdaya, komunikasi antar organisasi dan penguatan aktivitas, karakteristik agen pelaksana, kondisi sosial, ekonomi, dan politik (Subarsono, 2012: 90 \& 99).

Mengacu pada teori yang telah dijelaskan oleh Edward, Van Matter dan Van Horn bahwa berhasil atau gagalnya impelementasi kebijakan Kota Layak di Kota Pekanbaru ini akan sangat ditentukan oleh ; (1) aspek sumber daya yang ada, (2) komitmen agen pelaksana (implementor), (3) komunikasi antara agen pelaksana (implementor) dengan kelompok sasaran kebijakan.

\section{Aspek Sumber Daya}

Aspek sumber daya merupakan faktor penting yang menentukan berhasil atau tidaknya implementasi kebijakan Kota Layak Anak di Kota Pekanbaru. Sumberdaya tersebut dapat berupa sumberdaya manusianya, maupun sumber daya finansialnya.

Dari aspek sumber daya manusia, pengembangan kebijakan KLA di kota Pekanbaru ini secara kelembagaan berada di bawah koordinasi Badan Pemberdayaan Perempuan Masyarakat da Keluarga Berencana Kota Pekanbaru (BPPMKB). Terkait dengan hal ini walikota telah menerbitkan Keputusan Walikota Pekanbaru No. 144 Tahun 2013 tentang pembentukan Gugus Tugas Pengembangan Kota Layak Anak Kota Pekanbaru.

Untuk penanganan permasalahan anak korban kekerasan, di bawah koordinasi BPPMKB telah di bentuk Pusat Pelayanan Terpadu Perlindungan Perempuan dan Anak (P2TP2A), yaitu Pusat kegiatan Terpadu yang menyediakan pelayanan bagi perempuan dan anak korban kekerasan di Kota Pekanbaru.

P2TP2A Kota Pekanbaru dibentuk berdasarkan surat keputusan Walikota Pekanbaru No. 231 tahun 2013. Kegiatan P2TP2A pelayanan yang terintegrasi meliputi :
1. penanganan pengaduan

2. pelayanan kesehatan

3. rehabilitasi sosial

4. penegakan dan bantuan hukum

5. pelayanan pemulangan dan reintegrasi sosial

6. Rumah Aman ( shelter) melalui rujukan secara gratis.

\section{Komitmen Implementor}

Komitmen implementor ini mencakup tigal hal penting, yakni: (a) respon implementor terhadap kebijakan, yang akan mempengaruhi kemampuannya untuk melaksanakan kebijakan, (b) kognisi, yakni pemahamannya terhadap kebijakan, (c) prefensi nilai yang dimiliki oleh implementor (Van matter \& Van Horn dalam Subarsono, (2012: 101). Ketiga hal penting tersebut akan sulit tercapai jika aspek sumber daya belum maksimal.

\section{Komunikasi Antara Implementor dengan Kelompok Sasaran Kebijakan}

Komunikasi antara implementor dengan kelompok sasaran kebijakan KLA di Kota Pekanbaru sebetulnya akan terjalin dengan baik jika Forum Anak Kota Pekanbaru dapat difungsikan secara baik. Forum Anak Kota Pekanbaru itu seharusnya dapat menjadi wadah partisipasi bagi anak-anak di Kota Pekanbaru untuk ambil bagian dalam pembuatan kebijakan di Pekanbaru, sehingga anak dapat turus serta berpartisipasi dalam pembuatan kebijakan yang berpihak pada pemenuhan hak-hak anak. Partisipasi anak dalam keluarga, sekolah, dan masyarakat masih minim dan begitu juga partisipasi anak dalam pembangunan di Kota Pekanbaru khususnya dalam proses-proses kebijakan seperti Musyawarah Rencana Pembangunan Kecamatan (Musrenbangcam), dan Musyawarah Rencana Pembangunan (Musrenbang) pun belum nampak, yang mana hal-hal ini merupakan aspek penting dalam KLA. Dari kondisi tersebut terlihat bahwa fungsi Forum Anak Kota Pekanbaru ini belum terlihat secara nyata. 
Mustiqowati Ummul Fithriyyah, Studi Implementasi Kebijakan Kota Layak Anak KLA...

\section{Penelitian Terdahulu}

Ronawaty Anasiru. 2010. Implementasi Model-model Kebijakan Penanggulangan Anak Jalanan di Makasar (Jurnal Sosiokonsepsi, Bol. 16 No.02 tahun 2011). Hasil Penelitian ini menyebutkan bahwa dalam impelmentasi model-model kebijakan penanggulangan anak jalanan dapat dengan menggunakan 4 (emapt) tahapan, antara lain: 1) Model pendekatan berbasis panti sosial Institutional based service, 2) Model pendekatan berbasis keluarga/family based service, 3) Model pendekatan berbasis masyarakat/ community based service, 4) Model pendekatan berbasis semi panti sosial/ half way house service. Nelitian Dalam penelitian ini juga ditemukan mengenai masih kurangnya koordinasi antara pemerintah dan masyarakat.

Septo Pawelas Arso, Sutopo Patria Jati, Hervy Friska. 2012. Responsivitas Dinas Kesehatan Kota Semarang terhadap Pemenuhan Jaminan Hak-hak di Bidang Kesehatan Menuju Semarang Kota Layak Anak, Seminar Nasional World Fit for Children, Fakultas Kesehatan Masyarakat Universitas Diponegoro, 2012. Dari hasil penelitian Dinas Kesehatan Kota Semarang telah membuat agenda dan prioritas program yang menjadi kebutuhan anak di bidang kesehatan. Dalam upaya pengembangan program pelayanan, Dinas Kesehatan Kota Semarang memberdayakan dan menyiapkan Rencana Aksi Daerah KLA bersama-sama dengan stakeholder terkait. Kendala yang dihadapi adalah kurangnya sarana, kurangnya kordinasi dengan stakeholder dan kurangnya informasi tentang Forum Anak Semarang.

\section{METODE}

Metode yang dipergunakan dalam penelitian ini adalah metode penelitian deskriptif kualitatif yang didasarkan dari kajian literatur dan hasil wawancara yang telah dilakukan dari beberapa sumber yang dengan sengaja peneliti kumpulkan sesuai dengan kebutuhan informasi yang diperlukan. Kemudian menyeleksi data-data yang diperoleh sesuai dengan kebutuhan dan mengelompokkan data sesuai dengan jenis dan bentuknya. Kemudian diolah dan dianalisis secara deskriptif/kualitatif sesuai dengan materi permasalahan serta berupaya melakukan pemahaman mendalam, serta interprestasi yang dapat dipertanggung jawabkan kebenarannya.

\section{PEMBAHASAN}

Untuk mengefektifkan segala upaya untuk mewujudkan KLA, maka pendekatan KLA yang dilakukan perlu memperhatikan konsep dan tahapan pengembangan KLA sebagaimana diamanatkan dalam Peraturan Menteri Negara Pemberdayaan Perempuan dan Perlindungan Anak Nomor 11 Tahun 2011 tentang Kebijakan Pengembangan Kabupaten/Kota Layak Anak. Konsep KLA tersebut menjadi dasar bagi pengembangan KLA yang bertujuan untuk membangun inisiatif pemerintahan kabupaten/kota yang mengarah ada upaya transformasi konsep hak anak ke dalam kebijakan, program, dan kegiatan untuk menjamin terpenuhinya hak anak di kabupaten/kota (Panduan Pengembangan KLA, 2011).

Tahapan pengembangan KLA meliputi:

a. Persiapan, terdiri dari peningkatan komitmen dan pembentukan Gugus Tugas KLA Kabupaten/Kota dan pengumpulan data dasar.

1) Komitmen adalah dukungan dari para pengambil keputusan di kota Pekanbaru untuk menjadikan kota Pekanbaru menjadi KLA. Komitmen tersebut dapat tertuang dalam Perda, Perwako, Keputusan Walikota, Instruksi Walikota dan Surat Edaran Walikota.

2) Gugus Tuga KLA adalah lembaga koordinatif di tingkat kabupaten/kota yang mengoordinasikan upaya kebijakan, program, dan kegiatan untuk menjamin terpenuhinya hak anak. Gugus Tugas KLA di Kota Pekanbaru dibentuk berdasarkan Keputusan Walikota Pekanbaru Nomor 144 Tahun 2013 tentang Pembentukan Gugus Tugas Pengembangan Kota Layak Anak Kota Pekanbaru. Gugus Tugas Kota Pekanbaru ini bertanggungjawab mengawali dan mengawali 
pengembangan KLA di Kota Pekanbaru.

3) Pengumpulan data dasar; berkaitan situasi dan kondisi anak-anak di Kota Pekanbaru, yang seharusnya dapat disusun secara berkala dan berkesinambungan. Pengumpulan data dasar ini digunakan untuk: menentukan fokus program, menyusun kegiatan prioritas, melihat sebaran program/kegiatan anak lintas SKPD, dan menentukan lokasi percontohan. Lokasi percontohan di kota Pekanbaru adalah kecamatan Tenayan Raya yang mana telah dibentuk Gugus Tugas Pengembangan Kecamatan Layak Anak, berdasarkan pada Keputusan Camat Tenayan Raya No.82 Tahun 2014.

b. Perencanaan, terdiri dari penyusunan Rencana Aksi Daerah (RAD)-KLA.

1) Penyusunan. (Data KLA 2014). RAD-KLA berfungsi sebagai acuan penting untuk mengembangkan KLA secara sistematis, tearah, dan tepat sasaran.

2) Dalam penyusunan RAD-KLA, Gugus Tugas dan pihak-pihak terkait mempertimbangkan sesuai dengan RPJMN, RPJMD, Renstrada, visi, misi, kebijakan program dan kegiatan Kota agar RAD-KLA tidak tumpang tindih dengan berbagai rencana daerah yang sudah atau sedang berjalan.

3) Hal utama yang perlu diperhatikan dalam penyusunan RAD-KLA adalah RAD-KLA harus meliputi upaya penguatan kelembagaan anak dan pemenuhan hak anak dalam 5 (lima) klaster, yaitu: hak sipil dan kebebasan; lingkungan keluarga dan pengasuhan alternatif; kesehatan dasar dan kesejahteraan; pendidikan, pemanfaatan waktu luang dan kegiatan budaya; dan perlindungan khusus.

4) Menurut Buku Data KLA 2014 disebutkan bahwa RAD
Pengembangan KLA Kota

Pekanbaru masih dalam proses.

c. Pelaksanaan; dalam pelaksanaan suara anak harus diperhatikan, baik untuk memberi masukan mengenai bagaiman tanggapan mereka atas jalannya pelaksanaan yang dilakukan oleh para pemangku kepentingan, maupun terlibat langsung dalam pelaksanaan. Dalam hal ini Pemerintah Kota Pekanbaru telah membentuk Forum Anak Kota Pekanbaru yang telah dibentuk kepengurusannya untuk periode 20132016, berdasarkan Keputusan Walikota Pekanbaru Nomor 386. Namun Forum Anak Kota ini seolah hanya nama saja, belum terlihat secara nyata keterlibatan Forum Anak Kota tersebut. Padahal seharusnya Forum Anak Kota itu dapat menjadi wadah partisipasi bagi anakanak di Kota Pekanbaru untuk ambil bagian dalam pembuatan kebijakan di Pekanbaru.

d. Pemantauan, evaluasi, dan pelaporan Aspek penting yang harus diperhatikan dalam pemantaun, evaluasi dan pelaporan adalah capaian seluruh indikator KLA yang meliputi penguatan kelembagaan dan pemenuhan 5 (lima) klaster hak anak, yaitu; (1) hak sipil dan kebebasan, (2) lingkungan keluarga dan pengasuhan alternatif, (3) kesehatan dasar dan kesejahteraan, (4) pendidikan, pemanfaatan waktu luang, dan kegiatan budaya, (5) perlindungan khusus (Panduan Pengembangan KLA, 2011).

Berikutnya dalam pembahasan ini akan dibahas dua (2) hal, yaitu:

1) Base line anak di Kota Pekanbaru,

2) Implementasi Kebijakan Kota Layak Anak di Kota Pekanbaru

\section{Base Line Data Anak Di Kota Pekanbaru}

Anak merupakan potensi dan aset bangsa bagi pembangunan nasional, untuk itu pembinaannya perlu dilakukan sedini mungkin dengan mendorong pemerintah Kabupaten/kota untuk menyusun kebijakan yang berpihak pada kepentingan anak. 
Mustiqowati Ummul Fithriyyah, Studi Implementasi Kebijakan Kota Layak Anak KLA...

Sejak zaman Rasulullah Muhammad SAW sebetulnya telah dimulai gerakan perlindungan terhadap anak. Hal ini terbukti dengan langkah Rasulullah Muhammad mengkampanyekan anti kekerasan terhadap anak perempuan terhadap kaum Quraisy. Kala itu pada zaman jahililyyah anak laki-laki dipandang sebagai sosok yang ideal dan dalam pandangan mereka anak perempuan adalah aib dan kehinaan yang membebani kabilahnya (Mahjubah Magazine, 1993: 3). Dan atas kondisi ini Rasululullah pada akhirnya membongkar pemahaman jahiliyyah yang diskriminatif itu. Sekali lagi ini menunjukkan bahwa gerakan perlindungan terhadap anak sudah ada sejak dulu. Namun ironisnya, sampai saat ini, banyak pihak yang belum mempunyai pemahaman yang demikian. Terjadinya kasus pembunuhan anak, pelecehan seksual, pemaksaan menikah dini, mempekerjakan anak di bawah usia, menjadikan anak terlantar di jalanan, pengiriman anak ke luar negeri, dan bahkan penjualan anak. Berikut data banyaknya anak terlantar menurut jenis kelamin dan kecamatan di kota Pekanbaru;

Tabel 4.1.

Data Banyaknya Anak Terlantar Menurut Jenis Kelamin dan Kecamatan Di Kota Pekanbaru

Tahun 2013

\begin{tabular}{|c|c|c|c|c|}
\hline \multirow{2}{*}{ No } & \multirow{2}{*}{ Kecamatan } & \multicolumn{2}{|c|}{ Jenis Kelamin } & \multirow{2}{*}{ Jumlah } \\
\cline { 3 - 4 } & & Lak-laki & Perempuan & \\
\hline 1 & Tampan & 155 & 95 & 250 \\
\hline 2 & Payung Sekaki & 80 & 50 & 130 \\
\hline 3 & Bukit Raya & 76 & 29 & 105 \\
\hline 4 & Marpoyan Damai & 28 & 22 & 50 \\
\hline 5 & Tenayan Raya & 120 & 119 & 239 \\
\hline 6 & Lima Puluh & 22 & 14 & 36 \\
\hline 7 & Sail & 61 & 14 & 75 \\
\hline 8 & Pekanbaru Kota & 52 & 39 & 91 \\
\hline 9 & Sukajadi & 9 & 4 & 13 \\
\hline 10 & Senapelan & 69 & 29 & 98 \\
\hline 11 & Rumbai & 102 & 61 & 163 \\
\hline 12 & Rumbai Pesisir & 134 & 76 & 210 \\
\hline & JUMLAH & $\mathbf{9 0 8}$ & $\mathbf{5 5 2}$ & $\mathbf{1 . 4 6 0}$ \\
\hline
\end{tabular}

Sumber: Dinas Sosial dan Pemakaman Kota Pekanbaru, 2014

Tabel di atas menunjukkan tingginya angka anak terlantar di Pekanbaru. Hal ini bisa disebabkan keterbatasan ekonomi, bahkan ada beberapa anak yang hidup di jalanan menjadi pengemis dan gelandangan. Pemandangan seperti itu sering kita jumpai di pinggiran jalan atau di traffict light (lampu merah). Kondisi ini diperparah dengan banyaknya jumlah anak nakal yang terlihat dari tabel berikut ini: 
Tabel 4.2.

\section{Data Banyaknya Anak Nakal dan Wanita Rawan Sosial Ekonomi Di Kota Pekanbaru \\ Tahun 2013}

\begin{tabular}{|c|c|c|c|}
\hline No & Kecamatan & Anak Nakal & $\begin{array}{l}\text { Wanita Rawan } \\
\text { Sosial Ekonomi }\end{array}$ \\
\hline 1 & Tampan & 21 & 210 \\
\hline 2 & Payung Sekaki & 16 & 168 \\
\hline 3 & Bukit Raya & 17 & 255 \\
\hline 4 & Marpoyan Damai & 17 & 142 \\
\hline 5 & Tenayan Raya & 14 & 169 \\
\hline 6 & Lima Puluh & 17 & 167 \\
\hline 7 & Sail & 16 & 66 \\
\hline 8 & Pekanbaru Kota & 16 & 165 \\
\hline 9 & Sukajadi & 21 & 265 \\
\hline 10 & Senapelan & 21 & 85 \\
\hline 11 & Rumbai & 17 & 183 \\
\hline 12 & Rumbai Pesisir & 17 & 125 \\
\hline & JUMLAH & $\mathbf{2 1 0}$ & $\mathbf{2 . 0 0 0}$ \\
\hline
\end{tabular}

Sumber: Dinas Sosial dan Pemakaman Kota Pekanbaru, 2014

Kondisi kekerasan terhadap anak di Kota Pekanbaru terus meningkat dan semakin memprihatinkan, hingga Pekanbaru sempat mendapatkan julukan Kota Darurat Anak, sebagaimana yang disampaikan Helda Khamsy Kepala P2TP2A Kota Pekanbaru dalam Pekanbaru Pos edisi 20 Februari 2015.

"Tren peningkatan kasus selalu terjadi tiap tahun, Pekanbaru bisa dikatakan kota darurat anak"

Menurut data P2TP2A, per tanggal 20 Februari tahun 2015 sudah 16 korban kekerasan seksual terhadap anak di bawah umur yang melapor. Sedangkan di tahun 2013, total keseluruhan kasus hanya 17 kasus, naik di tahun 2014 menjadi 63 kasus.

Kepala Badan Pemberdayaan Perempuan dan Keluarga Bencana (BPMPKB) Kota Pekanbaru, M Amin juga mengatakan bahwa sejauh ini Kota Pekanbaru masih jauh sebagai kota layak anak seperti yang dicanangkan. Hal ini terlihat dari kasus eksploitasi dan pencabulan terhadap anak masih marak di Kota Pekanbaru. Jumlah laporan itu yakni dari bulan Januari hingga akhir Mei 2015, BPMPKB sudah menangani
62 kasus kekerasan baik terhadap anak maupun terhadap perempuan. Berikut ini kutipan wawancaranya:

"Kota Pekanbaru masih jauh sebagai kota layak anak seperti yang dicanangkan. Hal ini terlihat dari kasus eksploitasi dan pencabulan terhadap anak masih marak di Kota Pekanbaru. Dari 62 kasus itu, yang terbanyak adalah kasus kekerasan terhadap anak. Sepertiganya atau 20 kasus di antaranya adalah pencabulan. Sedangkan selebihnya adalah kasus KDRT (Kekerasan Dalam Rumah Tangga), rebutan hak asuh anak, kekerasan di sekolah dan perkosaan, Kondisi ini lebih memprihatinkan lagi karena dalam laporan yang diterima, pelaku umumnya adalah orang terdekat korban. Bahkan ada pelaku yang merupakan guru korban". (Indoriau.com, 24 Juli 2015).

Namun sangat mengejutkan bahwa tidak berapa lama setelah itu, pada tanggal 7 Agustus 2015, Tim penilaiaan dari Kementerian Pemberdayaan Perempuan dan Perlindungan Anak yang datang ke Pekanbaru menetapkan Pekanbaru sebagai kota layak 
Mustiqowati Ummul Fithriyyah, Studi Implementasi Kebijakan Kota Layak Anak KLA...

anak. Barangkali hal ini dikarenakan sebelumnya anak asli Pekanbaru, Bintang Purnama Putra dinobatkan sebagai Duta Anak Indonesia Wilayah Sumatera pada Konggres Anak di Batu Malang, Jawa Timur. (http://www.riauindikator.com/2432/anehpekanbaru-terima-penghargaan-kota-layakanak-.html).

Membincang tentang problematika anak, meskipun telah banyak regulasi yang mengatur tentang perlindungan anak namun tetap saja tindak kekerasan terhadap anak terus saja terjadi. Dan apapun bentuknya, baik kekerasan fisik, psikis, ekonomi, maupun seksual, pastilah mendatangkan ketidakadilan dan memunculkan kepedihan dan penderitaan bagi korbannya. Kasus kekerasan yang tak kalah berbahayanya adalah pemaksaan kehendak kepada anak seprti jadwal belajar dan kursus yang overload. Selain itu, ada juga bentuk pembiaran terhadap anak, seperti anak yang ditinggal bekerja seharian tanpa diperhatikan kebutuhan dasarnya.

Selain keluarga yang tidak ramah terhadap anak, fasilitas publik yang tersedia di Kota Pekanbaru juga belum sensitif terhadap anak, terbukti dengan minimnya tempat bermain anak. Kemudian persoalan anak yang lain yang tak kalah penting adalah sangat minimnya ruang berpartisipasi di ruang publik, baik dalam hal perencanaan, pelaksanaan, maupun evaluasi.

\section{Implementasi Kebijakan Kota Layak Anak di Kota Pekanbaru}

Mengacu pada teori yang telah dijelaskan oleh Edward, Van Matter dan Van Horn bahwa berhasil atau gagalnya impelementasi kebijakan Kota Layak di Kota Pekanbaru ini akan sangat dipengaruhi oleh ; (1) aspek sumber daya yang ada, (2) komitmen agen pelaksana (implementor), (3) komunikasi antara agen pelaksana (implementor) dengan kelompok sasaran kebijakan.

\section{Aspek Sumber Daya}

Aspek sumber daya merupakan faktor penting yang menentukan berhasil atau tidaknya implementasi kebijakan Kota Layak Anak di Kota Pekanbaru. Sumberdaya tersebut dapat berupa sumberdaya manusianya, maupun sumber daya finansialnya.

Dari aspek sumber daya manusia, pengembangan kebijakan KLA di kota Pekanbaru ini secara kelembagaan berada di bawah koordinasi Badan Pemberdayaan Perempuan Masyarakat da Keluarga Berencana Kota Pekanbaru (BPPMKB). Terkait dengan hal ini walikota telah menerbitkan Keputusan Walikota Pekanbaru No. 144 Tahun 2013 tentang pembentukan Gugus Tugas Pengembangan Kota Layak Anak Kota Pekanbaru.

Untuk penanganan permasalahan anak korban kekerasan, di bawah koordinasi BPPMKB telah di bentuk Pusat Pelayanan Terpadu Perlindungan Perempuan dan Anak (P2TP2A), yaitu Pusat kegiatan Terpadu yang menyediakan pelayanan bagi perempuan dan anak korban kekerasan di Kota Pekanbaru.

P2TP2A Kota Pekanbaru dibentuk berdasarkan surat keputusan Walikota Pekanbaru No. 231 tahun 2013. Kegiatan P2TP2A pelayanan yang terintegrasi meliputi :

7. penanganan pengaduan

8. pelayanan kesehatan

9. rehabilitasi sosial

10. penegakan dan bantuan hukum

11. pelayanan pemulangan dan reintegrasi sosial

12. Rumah Aman ( shelter) melalui rujukan secara gratis.

Namun belum banyak yang dapat dilakukan oleh P2TP2A terkait penanganan anak korban kekerasan.Data BPPMKB Pekanbaru menyebutkan bahwa selama tahun 2013, P2TP2A hanya menangani 19 kasus kekerasan terhadap perempuan dan anak. Jumlah korban yang melaporkan tindak kekerasan jumlahnya masih sangat sedikit dibandingkan dengan jumlah korban yang sebenarnya mengalami tindak kekerasan. Hal ini dikarenakan oleh kemampuan dari lembaga layanan P2TP2A masih minim dan yang terutama adalah penganggaran yang masih terbatas sangat mempengaruhi dalam memberikan pelayanan yang optimal (http://www.bppmkb.pekanbaru.go.id/index.ph p?option $=$ com_content $\&$ view $=$ article $\&$ id $=55$ : p2tp2a-pekanbaru-punya-sekretariat- 
sendiri\&catid $=16$ :beritapemberdayaanperemp uan\&Itemid=1).

Kutipan dari BPPMKB Kota Pekanbaru tersebut di atas menunjukkan bahwa aspek sumbedaya finansial dalam menentukan berhasil atau tidaknya implementasi kebijakan KLA di kota Pekanbaru masih belum optimal. Hal ini diperkuat lagi dengan hasil wawancara yang dilakukan kepada salah seorang anggota DPRD Kota Pekanbaru Roem Diani Dewi, juga menyebutkan bahwa penanganan kasus kekerasan terhadap anak dan pemberdayaan perempuan di Pekanbaru belum maksimal, dikarenakan rendahnya pengalokasian anggaran pemberdayaan anak dan perempuan. Berikut kutipan wawancaranya;

"Kondisi ini terjadi lebih akibat instansi terkait tidak maksimal membahas kebutuhan anggaran bagi perbaikan kesejahteraan anak dan perempuan di daerah itu, dan APBD Kota Pekanbaru tahun 2015 justru tidak akan banyak manfaatnya bagi kepentingan kegiatan pemberdayaan anak dan perempuan. Sejak dua tahun berturutturut anggaran pemberdayaan perempuan dan anak terus menurun sehingga dampaknya upaya pemberdayaan perempuan dan anak di Kota Pekanbaru belum maksimal. Pada tahun 2013 alokasi anggaran pemberdayaan anak di Kota Pekanbaru tercatat sebesar Rp250 juta, tahun 2014 turun menjadi Rp150 juta dan pada 2015 juga mengalami penurunan. (Antara, 9 Januari 2015).

Dari uraian di atas dapat disimpulkan bahwa implementasi kebijakan KLA di Kota Pekanbaru ditinjau dari aspek sumber daya masih belum optimal.

\section{Komitmen Implementor}

Komitmen implementor ini mencakup tigal hal penting, yakni: (a) respon implementor terhadap kebijakan, yang akan mempengaruhi kemampuannya untuk melaksanakan kebijakan, (b) kognisi, yakni pemahamannya terhadap kebijakan, (c) prefensi nilai yang dimiliki oleh implementor (Van matter \& Van Horn dalam Subarsono, (2012: 101). Ketiga hal penting tersebut akan sulit tercapai jika aspek sumber daya belum maksimal.

\section{Komunikasi Antara Implementor Dengan Kelompok Sasaran Kebijakan}

Komunikasi antara implementor dengan kelompok sasaran kebijakan KLA di Kota Pekanbaru sebetulnya akan terjalin dengan baik jika Forum Anak Kota Pekanbaru dapat difungsikan secara baik. Forum Anak Kota Pekanbaru itu seharusnya dapat menjadi wadah partisipasi bagi anak-anak di Kota Pekanbaru untuk ambil bagian dalam pembuatan kebijakan di Pekanbaru, sehingga anak dapat turus serta berpartisipasi dalam pembuatan kebijakan yang berpihak pada pemenuhan hak-hak anak. Partisipasi anak dalam keluarga, sekolah, dan masyarakat masih minim dan begitu juga partisipasi anak dalam pembangunan di Kota Pekanbaru khususnya dalam proses-proses kebijakan seperti Musyawarah Rencana Pembangunan Kecamatan (Musrenbangcam), dan Musyawarah Rencana Pembangunan (Musrenbang) pun belum nampak, yang mana hal-hal ini merupakan aspek penting dalam KLA. Dari kondisi tersebut terlihat bahwa fungsi Forum Anak Kota Pekanbaru ini belum terlihat secara nyata.

Dari sekian tahapan pengembangan kebijakan KLA, Kota Pekanbaru masih harus terus berproses untuk betul-betul mewujudkan kota Pekanbaru menjadi Kota Layak Anak.

\section{PENUTUP}

\section{Simpulan}

Dari uraian di atas, beberapa hal yang dapat disimpulkan adalah:

1. Persoalan anak di Pekanbaru masih sangat komplek, mulai dari kekerasan terhadap anak, minimnya fasilitas publik bagi anak, dan minimnya keterlibatan/pelibatan partisipasi anak di ranah publik.

2. Dilihat dari tahapan pengembangan kebijakan KLA di Kota Pekanbaru, hanya pembentukan Gugus Tugas dan Forum Anak Kota Pekanbaru yang sudah 
Mustiqowati Ummul Fithriyyah, Studi Implementasi Kebijakan Kota Layak Anak KLA...

terlaksana. Namun peran Forum Anak itupun belum maksimal. Sedangkan yang lain belum tercapai secara maksimal, meskipun pada Agustus 2015 Pekanbaru telah dinyatakan sebagai Kota Layak Anak.

3. Situasi pemenuhan dan sipil dan partisipasi anak masih minim. Hal tersebut dapat dilihat dari belum adanya keterlibatan anak dalam musrenbang baik tingkat kota, kecamatan, maupun kelurahan, belum tersedianya pusat informasi da komunikasi berbasis anak.

\section{Hambatan-hambatan}

Hambatan - hambatan dalam implementasi kebijakan Kota Layak Anak di Kota Pekanbaru adalah sebagai berikut:

1. Program KLA belum populer di tingkatan SKPD di Kota Pekanbaru dan secara kelembagaan SKPD masih bersifat egosektoral sehingga sulit mengintegrasikan issu anak ke dalam penyusunan program SKPD dan juga penyusunan RAD-KLA.

2. Kapasitas kelembagaan pelaksana kurang memadai.

3. Belum adanya anggaran berbasis kebutuhan anak dalam APBD.

4. Belum tercapainya kemitraan antara pemerintah, swasta, organisasi masyarakat, maupun masyarakat sendiri termasuk anak, dalam upaya bersamasama mewujudkan Kota Pekanbaru menjadi Kota Layak Anak sesuai dengan indikator-indikator yang telah ditetapkan pada Peraturan Menteri Negara PPPA RI No. 12 Tahun 2011.

\section{Rekomendasi}

Berdasarkan pada hambatan-hambatan yang telah terurai di atas, maka peneliti merekomendasikan beberapa langkah sebagai berikut:

1. Menumbuhkan komitem bersama di semua SKPD dan pimpinan daerah (walikota dan lembaga legislatif) untuk dapat mengintegrasikan issu anak ke dalam penyusunan program SKPD dan penyusunan RAD-KLA, agar dapat terintegrasi dengan dokumen perencanaan daerah: RPJMD atau Renstrada/RKPD.

2. Penguatan kapasitas kelembagaan Gugus Tugas KLA baik penguatan sumber daya manusia maupun sarana prasarana dan penguatan kapasitas kelembagaan Forum Anak Kota Pekanbaru melalui program pendampingan.

3. Mengawal anggaran berbasis kebutuhan anak dalam APBD.

4. Menumbuhkembangkan kemitraan antar pemerintah, swasta, organisasi masyarakat, maupun masyarakat sendiri termasuk anak, dalam upaya bersamasama mewujudkan Kota Pekanbaru menjadi Kota Layak Anak sesuai dengan indikator-indikator yang telah ditetapkan pada Peraturan Menteri Negara PPPA RI No. 12 Tahun 2011.

\section{DAFTAR PUSTAKA}

BPS Kota Pekanbaru. 2014.

Data KLA, 2014

Hamid Patilima. 2004. Persepsi Anak Mengenai Lingkungan Kota Studi Kasus di Kelurahan Kwitan. Jakarta Pusat (Tesis). Jakarta: Pasca Sarjana UI, Kajian Pengembangan Perkotaan.

Hamid Pattilina. 2008. Kota Layak Anak, http://www.ykai.net/index.php?view $=$ artikel\&id=97:kota-layak-anak.

LAKIP KPP-PA, 2013

Mahjubah Magazine. 1993. Pendidikan Anak Sejak Dini Hingga Masa Depan. Jakarta: CV. Firdaus.

Naning Pudjijulianingsih. 2009. Meningkatkan IPM Melalui Perwujudan Kabupaten/Kota Layak Anak (makalah)

Panduan Kebijakan Pengembangan Kota Layak Anak, Kementerian Pemberdayaan Perempuan Republik Indonesia. Tahun 2006. 
Peraturan Menteri Negara Pemberdayaan Perempuan dan Perlindungan Anak Republik Indonesia Nomor 11 tahun 2011 tentang Kebijakan Pengembangan Kabupaten/Kota Layak Anak

Peraturan Menteri Negara Pemberdayaan Perempuan dan Perlindungan Anak Republik Indonesia Nomor 12 tahun 2011 tentang Indikator Kabupaten/Kota Layak Anak

Peraturan Menteri Negara Pemberdayaan Perempuan dan Perlindungan Anak Republik Indonesia Nomor 13 tahun 2011 tentang Panduan Pengembangan Kabupaten/Kota Layak Anak (KLA)

Peraturan Menteri Negara Pemberdayaan Perempuan dan Perlindungan Anak Republik Indonesia Nomor 14 tahun 2011 tentang Panduan Evaluasi Kabupaten/Kota Layak Anak.

Riant Nugroho. 2009. Public Policy. Jakarta: PT. Gramedia.

Siti Malaiha Dewi. 2011. Transformasi Kudus Sebagai Kota Layak Anak (Tinjauan Atas Pemenuhan Hak Sipil dan Partisipasi) (Jurnal "Muwazah" vol.3 No.1).

Subarsono. 2012. Analisis Kebijakan Publik. Yogyakarta: Pustaka Pelajar.

Sugitono. 2005. Memahami Penelitian Kualitatif. Bandung: Alfabeta.

WJS. Poedarminta. 1992. Kamus Umum Bahasa Indonesia. Jakarta: Balai Pustaka.

http://www.pekanbarumx.co/baca/1322/alama k-pekanbaru-darurat-anak.html http://bp3akb.riau.go.id/index.php/berita/sekr etariat/438-badan-pemberdayaanperempuan-perlindungan-anak-dankb-provinsi-riau-failitasipembentukan-forum-anakkecamatan-se-pekanbaru

http://www.riauindikator.com/2432/anehpekanbaru-terima-penghargaan-kotalayak-anak-.html

http://www.rri.co.id/pekanbaru/post/berita/12 6941/daerah/pengetahuan_tentang_a nti_kekerasan_terhadap_anak_dan_p erempuan_meningkat.html 